\title{
High-technology based startup in agribusiness sector: mapping linkages, products and services
}

\author{
Startups de base tecnológica no setor do agronegócio: mapeamento \\ de ligações, produtos e serviços
}

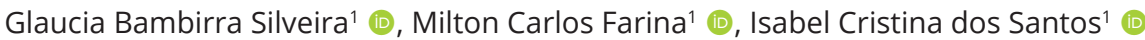

1Programa de Pós-graduação em Administração, Universidade Municipal de São Caetano do Sul (USCS), São Caetano do Sul (SP), Brasil. E-mails: glauciabambirra@gmail.com; isa.santos.sjc@gmail.com; milton.farina@prof.uscs.edu.br

How to cite: Silveira, G. B., Farina, M. C., \& Santos, I. C. (2023). High-technology based startup in agribusiness sector: mapping linkages, products and services. Revista de Economia e Sociologia Rural, 61(1), e246210. https://doi. org/10.1590/1806-9479.2021.246210

\begin{abstract}
The agribusiness sector has experienced a significant pace of technological evolution. New resources, such as the use of drones, the internet of things, and satellite communication have been fundamental in the emergence of AgTechs, technological companies that have emerged from agribusiness. This article aims to map São Paulo AgTechs and the products and services they offer. This article contributes to the advancement of knowledge about AgTechs and their transformation of the Brazilian agribusiness field. AgTechs have expanded and strengthened the agribusiness sector, which represented approximately $21.4 \%$ of Brazilian GDP in 2019, and 26.6\% in 2020, despite the political-health crisis and its challenge, it has continued the growth and investment trajectory in Rand and Development, while seeking to increase efficiency in interactions. This qualitative study is exploratory and has a bibliographic design. The data were collected from the Brazilian Association of Startups, Global Entrepreneurship Monitor reports, websites of AgTechs in São Paulo state, and Web of Science. The main results indicate the importance of the São Paulo ecosystem, in which are located $26 \%$ of Brazilian AgTechs, the largest concentration in the country. The products and services generated at AgTechs are high tech. In the state of São Paulo, there are three communities that interact with AgTechs and form an entrepreneur-innovative ecosystem.
\end{abstract}

Keywords: entrepreneurial and innovative ecosystem, startup communities, agribusiness, technological innovation, social network analysis.

Resumo: O setor do agronegócio tem experimentado um ritmo significativo de evolução tecnológica. Novos recursos como o uso de drones, a internet das coisas e a comunicação via satélite, foram fundamentais para o surgimento das AgTechs, empresas de tecnologia que surgiram do agronegócio. Este artigo tem como objetivo mapear as AgTechs paulistas e os produtos e serviços que oferecem. Este artigo contribui para o avanço do conhecimento sobre as AgTechs e a transformação no campo do agronegócio brasileiro. As AgTechs expandiram e fortaleceram o setor do agronegócio, que representou aproximadamente 21,4\% do PIB brasileiro em 2019 e 26,6\% em 2020, apesar da crise político-sanitária e tem como desafio continuar a trajetória de crescimento e de investimento e Pesquisa e Desenvolvimento, enquanto busca aumentar a eficiência nas interações. Este estudo qualitativo é exploratório e tem um desenho bibliográfico. Os dados foram obtidos na base de dados da Associação Brasileira de Startups, relatórios do Global Entrepreneurship Monitor, sites da AgTechs no estado de São Paulo e Web of Science. Os principais resultados indicam a importância do ecossistema paulista, no qual estão localizadas 26\% das AgTechs brasileiras, a maior concentração do país. Os produtos e serviços gerados pelas AgTechs são de alta tecnologia. No estado de São Paulo, são três comunidades que interagem com as AgTechs e formam um ecossistema empreendedorinovador. As interações ocorrem entre as AgTechs, bem como entre elas e as empresas de médio e grande porte, poder público e as instituições de ensino e pesquisa, gerando oportunidades de desenvolvimento de novos produtos e serviços, alcance de novos mercados que proporcionam eficiência e fortalecimento das startups no mercado competitivo.

Palavras-chave: ecossistema empreendedor e inovador, comunidades de inicialização, agronegócio, inovação tecnológica, análise de redes sociais. 


\section{Introduction}

The Brazilian Ministry of Agriculture, Livestock and Food Supply (MAPA) has highlighted that agribusiness is an important sector in strengthening the economy (Brasil, 2019). Globally, agribusiness is considered one of the largest fields to foster technological innovation (Liga Insigths AgTech, 2019). In 2018, the agribusiness sector was responsible for $20.8 \%$ of total Gross Domestic Product (GDP), which rose to $21.4 \%$ in 2019 and is expected to grow further in 2020, according to the Center for Advanced Studies on Applied Economics (Centro de Estudos Avançados em Economia Aplicada, 2020).

Agribusiness employed about 18.25 million people in Brazil in 2019, accounting for $19.54 \%$ of the labor market share in the country; this was an increase of 0.8\% (145,000 employees) in 2018 (Centro de Estudos Avançados em Economia Aplicada, 2019), indicating growth in the sector.

Agribusiness can be classified according to three core activities: primary activities that consist of rural production; secondary activities that include agroindustry and agricultural input industries; and tertiary activities that comprise the transportation and marketing of agricultural goods (Instituto Brasileiro de Geografia e Estatistica, 2019). The demand to produce food for export, and to increase the quantity and quality of that food, has resulted in the agribusiness sector being a catalyst for significant technological changes from the post-war period, through the Green Revolution of the 1960s, to the digital revolution that has characterized the microelectronics sector, especially since the 1980s (Perez, 2010).

Technological advances in agribusiness have prospered due to technological developments. These technological advances in agribusiness have caused changes and made it possible to add value and income throughout the agro-industrial complex, especially in those where new technologies are adopted (Sesso Filho et al., 2022). The sector underwent a modernization process that involved "the replacement of agriculture, previously labor-intensive, with capital-intensive agriculture" in the post-war period, but it was in the late 1980s that the sector experienced "significant increases in agricultural production and productivity ... resulting in income gains for the sector" (Almeida, 2007, pp. 8-9). Since the 1990s, tractors and agricultural machinery have evolved to incorporate embedded technology.

On technological and economic development, Sesso Filho et al. (2022) points out that the agricultural machinery and equipment sectors can connect traditional agricultural production to the agro-industrial processing chain, which adopts high technology, and brings together suppliers and services that nurture both sectors with substantial knowledge and learning spillovers crossing the agriculture and manufacture sectors.

Agricultural research is a fertile field for the development of new technologies, particularly with the aim of increasing productivity (Santos et al., 2020). Especially relevant are the fields of biotechnology and microelectronics, and the emergence of applications, software, drones, and robots have enabled and enhanced better management and production in agribusiness, as well as bringing producers and suppliers of equipment, systems, and productive inputs closer together.

In January 2019, the Ministry of Economy reported an increase in exports of agricultural products in 2018, indicating the sector's attractiveness to investors, which includes opportunities for startups to develop technologies that enable greater control of livestock and agricultural production, as well as to create marketing platforms (Brasil, 2019).

High technology-based startups in agricultural sector - AgTechs - have emerged increasing the efficiency and effectiveness of production process and changing how farms operate (CBinsights, 2019). In addition, startups can contribute to the achievement of sustainable development goals, 
as set out in the 2030 Agenda of the United Nations (UN), especially the second objective: to increase agricultural productivity, to invest in rural infrastructure, and to develop technologies in the agricultural sector, in order to combat hunger and achieve food and nutritional security, which consists of the right of everyone to have access to quality food in sufficient quantity, without compromising access to other essential needs for life (United Nations, 2015).

And, finally, technological evolution and adoption of new technologies in the agribusiness sector have positive effects on productivity and, as a phenomenon, may explain the effect that "increased technical progress has on the generation of jobs in the primary sector for Brazil" (Fiuza-Moura et al., 2017, p. 138). The agribusiness sector has attracted entrepreneurs with diversified higher education, many of them in careers unrelated to agriculture. Given the multidisciplinary knowledge applied in the Agribusiness field, job opportunities open for agronomists, biologists, computer scientists, engineers (Marjotta-Maistro et al., 2019).

Organizations seek to promote sustainable development as a way of survival, while contributing to a better quality of life because, in the future, there will be no opportunities or space in the market for companies that do not have sustainable attitudes (Moori et al., 2018).

Aligned with the second objective of the 2030 Agenda, the Brazilian Agricultural Research Corporation (EMBRAPA), which discussed the concept of precision agriculture in a 2014 publication (Bernardi et al., 2014), launched its own agenda that focused on agricultural development in line with the goals established by the UN. This EMBRAPA Agenda addresses topics such as the trajectory of Brazilian agriculture, megatrends in the sector, socio-economic transformations, the increase and sustainability of agricultural systems, climate change, greater consumer activity, and the convergence between technologies (Empresa Brasileira de Pesquisa Agropecuária, 2018).

The use of nanotechnology, biotechnology, information technology, cognitive science, among other things, is supporting the country's economic and scientific development and contributing to the creation of disruptive products and processes. This phenomenon has led to the emergence of both traditional and technology-based startups, with the last one having greater prominence for the country's economic development, as they contribute to the formation of a high-tech jobs sector (Padrão \& Andreassi, 2013). A startup is an innovative company whose objective is to offer services or products of an incremental and/or disruptive nature to the market (Brasil, 2019).

Implementing Agriculture 4.0 in Brazil presents great challenges, mostly regarding the large areas that still operate in the traditional system. These producers will be challenged by the demands for better control and productivity of the space of growing cattle and cultivation, provided by the digital technology and artificial intelligence (Cunha et al., 2019).

And even though there are challenges, agribusiness growth estimates in Brazil indicate the sector's optimism regarding the performance that the country has achieved vis-à-vis the main producers. It is estimated that "an increase of 8.6 million hectares of planted area" by 2023 (Mauri et al., 2017), what should reflect an increase in production, since Brazilian agriculture operates within the parameters of the Soil Economy.

Thus, considering the growth of information technology and the emergence and growth of startups with a focus on agribusiness, the following research question was elaborated: How are startups and communities that are part of associations called AgTechs, Agritechs or Agrotechs in the state of São Paulo related to their products and services?

The aim of this work is to map the AgTechs in São Paulo that are linked to the startup communities as well as the products and services they offer to the agribusiness sector. 
The approach to the theme contributes to the academic debate by focusing on the AgTech networks in the state of São Paulo. It aims to improve knowledge about interorganizational relations, with a focus on the products and services offered and on the geographical location.

The choice of the state of São Paulo was due to it being considered the state with the largest number of Brazilian AgTechs (about $26 \%$ of the total in Brazil) and having three large communities of startups located in the state capital (the city of São Paulo), Piracicaba, and São José dos Campos (Startse, 2019; Associação Brasileira de Startups, 2019).

\section{Theoretical review}

This section presents the concepts that will be used throughout the article. First, it addresses to the technology and innovation as important drivers in the development of startups, and then it considers the organizations and their social networks that influence the creation and development of São Paulo's AgTechs.

\subsection{Technology and innovation}

With advances in information technology and the internet, as well as the growing use of satellites and artificial intelligence, windows of opportunity have been created for entrepreneurs, who, by combining innovation, knowledge, and entrepreneurship, drive the main engines of economic, social, and cultural development, with major implications for public policy (Malerba \& McKelvey, 2019).

There is a continuum in scientific and technological knowledge that reflects technological changes and their impact on the economy. According to Kondratieff (1935), capitalist economies are dynamic, complex, and cyclical. Economic cycles, termed by Kondratieff as long waves (or K-waves), last about 48-60 years and begin with radical changes in technology and relevant scientific findings that influence economic development.

The disruptive technologies that were responsible for each of the three K-waves were steam engine (1800), the railroad (1850), and the discovery of steel (1900) (Kondratieff, 1935). Two representatives of the neo-Schumpeterian school of thought, Freeman \& Soete (1997), updated the K-waves following implications pointed out by Schumpeter (1935) and added other disruptive innovations: mass production (wave 4), the development of the microelectronics (wave 5), and environmental and health technologies (wave 6).

Kondratieff's (1935) work was revisited by Nelson \& Winter (1982) who pointed out that the fifth wave of economic change generated by the domain of information and communication technologies, and, more generally, of microelectronics. The sixth wave was characterized by the application of new technologies aimed at the environment and health. In this stage, microelectronics, developments in technological resources, and artificial intelligence offer new solutions to problems based on information and decisions.

The evolution of data science, on which the internet of things is based, has been debated as a technology that underlies the fourth Industrial Revolution. Technological advances, such as the emergence of blockchain, 3D printing, and artificial intelligence, have impacted the complexity of business (Magalhães \& Vendramini, 2018). As a result of these advancements, some researchers conjecture a new wave of the economic change due to technological evolution. The Table 1 exhibits the waves as described by the Authors. 
Table 1: Waves of economic cycles

\begin{tabular}{|c|c|c|c|c|}
\hline & Waves & $\begin{array}{l}\text { Science and technology, } \\
\text { education, and training }\end{array}$ & $\begin{array}{l}\text { Transport and } \\
\text { communication }\end{array}$ & $\begin{array}{l}\text { Energy } \\
\text { systems }\end{array}$ \\
\hline I & $\begin{array}{l}\text { Industrial Revolution } \\
(1780-1840)\end{array}$ & $\begin{array}{l}\text { Learning by doing, } \\
\text { scientific societies }\end{array}$ & Canals, carriage roads & Waterpower \\
\hline II & $\begin{array}{l}\text { Age of steam power and } \\
\text { railways (1840-1890) }\end{array}$ & $\begin{array}{l}\text { Professional mechanical } \\
\text { and civil engineers }\end{array}$ & Railways (iron), telegraph & Steam power \\
\hline III & $\begin{array}{l}\text { Age of electricity and } \\
\text { steel (1890-1940) }\end{array}$ & $\begin{array}{l}\text { Industrial Research \& } \\
\text { Development (RD) labs, } \\
\text { chemicals, and electrical, } \\
\text { national laboratories }\end{array}$ & Railways (steel), telephone & Electricity \\
\hline IV & $\begin{array}{l}\text { Age of mass production } \\
(1940-1990)\end{array}$ & $\begin{array}{l}\text { Large-scale industrial and } \\
\text { government RD }\end{array}$ & $\begin{array}{l}\text { Motor railways, radio and } \\
\text { TV, airlines }\end{array}$ & Oil \\
\hline V & $\begin{array}{l}\text { Age of microelectronics } \\
\text { and computer networks } \\
(1990-\text { ?) }\end{array}$ & $\begin{array}{l}\text { Data networks, RD } \\
\text { global networks, lifelong } \\
\text { education, and training }\end{array}$ & $\begin{array}{l}\text { Information railways, } \\
\text { digital networks }\end{array}$ & Gas/Oil \\
\hline $\mathrm{VI}$ & $\begin{array}{l}\text { Environmental and } \\
\text { health technologies }\end{array}$ & $\begin{array}{l}\text { Biotechnology, genetics, } \\
\text { and nanotechnology }\end{array}$ & $\begin{array}{l}\text { Telematics and } \\
\text { teleworking }\end{array}$ & $\begin{array}{l}\text { Renewable } \\
\text { energy }\end{array}$ \\
\hline
\end{tabular}

Source: Freeman \& Soete (1997).

The waves are characterized by specific social, economic, political, and technological factors. Freeman \& Perez (1988) referred to technological changes as a process involving a change in the techno-economic paradigm, which occurs with the emergence of new technologies, products, and services that affect the economy and society and facilitate economic reorganization after a period of changes or crisis.

The influence of information and communication technology in the agricultural field has contributed to advances in precision agriculture, which is considered a new way of managing agricultural production and involves the use of technology that can help optimize production (Molin, 2003). The precision agriculture aims to maximize efficiency applying cutting-edge technology, information systems tools, machinery, and special techniques.

Precision agriculture is considered a management system that uses new information technologies. Its use of data obtained by satellites enables it to transform agriculture by enhancing knowledge of resources and production, which facilitates decision-making by rural entrepreneurs and increases productivity (Tschiedel \& Ferreira, 2002; Molin, 2003). In addition, it can help to lower costs, increase profits, optimize the application of inputs, and reduce environmental pollution (Shiratsuchi, 2012).

The stages of agriculture, to which precision agriculture can be applied, are divided into soil preparation, planting, monitoring, and harvesting (Miranda et al., 2017). There are, in turn, four phases of precision agriculture: the first step consists of collecting existing data through sensors, global positioning systems (GPS), soil analysis, productivity maps, and crop monitoring; the second involves data processing; the third is the interpretation of information obtained by agronomists, producers, and specialists; and the fourth is the application of knowledge and the use of precision agriculture in planting, fertilizing, spraying, cultivating, and use of robotic vehicles (Conceição \& Braga, 2015).

Precision agriculture is a broad field within which AgTechs can develop new products and services. However, despite a growing number of these startups in Brazil, some obstacles remain, such as bureaucratic and structural challenges (Liga Insights AgTechs, 2019).

While identifying the limiting factors to the Brazilian entrepreneurs, the Global Entrepreneurship Monitor Report (Global Entrepreneurship Monitor, 2017) specialists concluded as the most cited obstacles to entrepreneur what follows: government policies (86.7\%), the lack of financial 
support (45\%), and the political and economic context (28.3\%). On the other hand, the specialists indicated as favorable factors: the capacity and composition of the Brazilian population was pointed as the most cited factor with $65 \%$ of the answers, the opening of the market, with $50 \%$, and government policies in support to the entrepreneurship, with $26.7 \%$ of the answers (Global Entrepreneurship Monitor, 2017).

The factor of "government policies" was regarded both as a limiting factor and as a favorable factor. On the one hand, government policies can facilitate the creation of companies, for example, through the Law of the Individual Microentrepreneur (LIM); on the other hand, government policies can make entrepreneurship difficult, because of the extensive bureaucracy faced by entrepreneurs, especially when opening and closing companies. In the evaluation of the Global Entrepreneurship Monitor (2017) report, Brazil ranks 50th out of 54 countries in relation to government policies for entrepreneurship.

Malerba \& McKelvey (2019) argued that the entrepreneur assumes the risks of the business and, consequently, makes profits by transforming ideas into innovations. In doing so, the business is a disruptive force that drives the economy and generates economic growth.

Technological entrepreneurship is considered an engine for economic development. Thus, the role of AgTechs is valued for transforming present opportunities into future economic growth. On the Silicon Valley (2019) website, a section dedicated exclusively to agribusiness startups points out that artificial intelligence, cloud computing, and technology applied to agribusiness contribute to increases in yields and profits in the agricultural sector.

The most competitive organizations tend to seek disruptive innovations with a special effort to develop innovative projects that reach new markets, causing a kind of creative destruction (Christensen, 2013; Davis \& Tomoda, 2018). Due to its emphasis on production and research, the Brazilian agribusiness sector has proved to be highly competitive throughout the country's economic history (Santos et al., 2020).

The main results of the evolution of the productive and scientific capacity of the sector are reflected in the portfolio of disruptive technologies related to AgTechs that are being gradually applied in agribusiness. These technologies are smart farming, precision farming, farming systems and machinery, vertical farming, crop efficiency, big data, startups, satellites, and the internet of things (Silicon Valley, 2019)

The receptivity of Brazilian farmers to technological innovations is considered high (Noce, 2017), so that there has been an accelerated pace of technological investments in agribusiness by AgTechs. According to a survey by ABStartups, AgTechs are companies that invest significantly in technology and focus on technological entrepreneurship (AgTech Garage, 2019). They demonstrate technological mastery in an economically relevant sector both nationally and globally.

The technological domain and the investments in agricultural research and development by universities and research centers have spread to technology-based enterprises, attracted investors, and generated a cycle of interactions that thrive in innovation environments (Santos et al., 2020). The interactions among external agents that promote innovation, such as universities, research centers, and development agencies, are guided by trust, partnership, and learning. Without them, Brazilian small and medium-sized enterprises would find it harder to innovate, compete, and prosper (Silva et al., 2016).

\subsection{Organization in networks}

AgTechs are startups that offer agricultural solutions by designing and producing equipment, facilitating transgenic culture and genetic improvement, performing GPS monitoring, creating 
data management software, automation, and robotics, and improving supply chain management and logistics (Global Startup Ecosystem Report, 2018).

The Global Startup Ecosystem Report (2018) considered the lifecycle of 12 startup subsectors, including AgTech, which has experienced rapid global growth of around 101\% in the last five years, despite representing only $0.6 \%$ of all global startups (Global Startup Ecosystem Report, 2018). In 2020, the Global Startup Ecosystem Report (2020) placed São Paulo 30th in the world ranking of ecosystems.

In Brazil, the financial institution BTG Pactual acquired a stake in Agronow, an agricultural startup that monitors crops (Mendes, 2019), signaling the attractiveness of AgTechs in the Brazilian entrepreneurial and economic market.

The creation of AgTechs is closely related to entrepreneurship, which can be an individual phenomenon that consists of creating a business due to opportunity or need, or a social phenomenon in which a community is formed to seek integration and joint solutions to overcome challenges (Baggio \& Baggio, 2015). Besides, such a community can be defined as an ecosystem comprising startups, government, universities, investors, mentors, and large companies, all of whom cooperate to seek solutions that add value. Usually, the leaders of the startup communities are entrepreneurs (Feld, 2012).

The entrepreneurial ecosystem consists of six interconnected attributes: favorable culture, leadership, sources of financing, quality human capital, market, and infrastructure. Major changes occur due to the interaction of these attributes, which together drive the system and generate success (Isenberg, 2011). The innovation ecosystem is based on interaction developed with different actors aiming to generate new products and services to consumers (Santos et al., 2020). But, in both ecosystems, social relations are an important asset towards the improvement of innovative capacity. Cooperation and trust act as a pre-condition to reach collective efficiency. Social interactions, systematized through networks, generally impact organizational and marketing innovations (Hoffmann et al., 2016).

The dissemination of knowledge among the members of the network is important for the successful establishment of entrepreneurial ecosystems. The development of information technologies has facilitated communication among members of the network. Another important element is the mutual trust between the parties that facilitates an easier exchange of knowledge (Balestrin \& Verschoore, 2007), thereby strengthening interpersonal relationships. Participation in industry events to exchange experiences also contributes to the formation of a network of companies (Toigo, 2018). This network cooperates to increase the competitiveness and efficiency of its members, ultimately advancing regional and national economic development due to the increasing supply of jobs and income.

Federal Decree No. 9.283/ 018 conceptualizes the innovation ecosystem as a space for interaction between entrepreneurs, investors, technology parks, smart cities, and innovation districts to enhance the exchange of information and to add knowledge (Brasil, 2018). These ecosystems can be physically delineated or not, if they maintain effective relationship ties (Audretsch et al., 2019). Contrary to the premise that distance is not important, Toigo (2018) showed that geographical proximity is important in the exchange of information and knowledge.

Thus, the existence of relationships and connections between participants motivated to exchange experiences, knowledge, and mutual assistance are presuppositions for the formation of a network. Social network analysis (SNA) makes it possible to understand the structure and relationships of such a network (Leonardo et al., 2019). Aiming to generate value to businesses, the participation of organizations and individuals in networks is a strategic tool, since it provides 
benefits of social capital that enable individual efforts to obtain knowledge and improve the efficiency of daily tasks (Farina et al., 2013).

The social structures formed through the Social Network Analysis (SNA) are identified according to nodes, which are people, companies, types of activities or things within the analyzed network, and the bonds, relationships, or interactions that connect them (Borgatti et al., 2002; Farina et al., 2013). The social network can be represented by a graph, within which one of the measures is the centrality of degree. This allows analysis of the individuals that make up the network and identification of the degree of connectivity and the connections between the network's members. Nodes are the joining of members with common goals, and the bonds, which are represented by lines, are the links between them. The bonds, or relationships, are established by the network's parts, and the flows indicate the direction of the bond established (Borgatti et al., 2002; Fialho, 2014; Freitas, 2010).

Networks can be built based on actors (nodes) and the relationships between them (onemode analysis of network); however, it is more common for networks to consist of relationships between actors and characteristics or occurrences (two-mode analysis of network), with the result that networks can be built based on these characteristics. For example, it is possible to build a network of companies that sell the same products or services, which allows different and interesting analyses of the macro-microstructure of the network. It is possible to investigate suppliers or customers of companies that offer similar products; or, based on the products, it is possible to analyze the companies' field of action. This macro-microstructure is addressed by, among others, Hanneman \& Riddle (2005).

\section{Method and materials}

This research used a qualitative methodology in the form of an exploratory study, which is recommended to clarify and develop new concepts and to provide insights into the researched subject (Gil, 2019). In the present study, the exploratory research was conducted with the purpose of identifying social networks and exchanges between members of the network. For this, an SNA approach was adopted, and the Ucinet software was used. The command used in the Ucinet software was called "affiliations" and allowed, based on an actor-relation-characteristic set (two-mode network), an actor-actor network (one-mode network) to be analyzed.

This study was preceded by a bibliographical survey of scientific articles from 2015 to 2019 and available in the Web of Science database, using the descriptors AgTech, AgriTech, and AgroTech. Four articles were found. Furthermore, in the development of the research, secondary databases were consulted, especially on the websites of Startupbase, ABStartup, and AgTechs in São Paulo to map the São Paulo AgTechs ecosystem.

Information was compiled from 12,741 startups in Brazil with various areas of operation, and from 74 Brazilian communities distributed in 574 municipalities linked to the Brazilian Startup Association. According to Instituto Brasileiro de Geografia e Estatistica (2019), Brazil has 5,570 municipalities, so only $10.3 \%$ of Brazilian municipalities are in the startups segment. From the total number of startups, 3,731 are in the state of São Paulo and represent diverse sectors. Based on the descriptor AgTech, from the 350 located in Brazil, 315 are in the agribusiness segment (Associação Brasileira de Startups, 2019). From the startups in São Paulo that operate in the agribusiness sector, 90 AgTechs were identified. They are distributed in: São Paulo city, with 47 AgTechs; São José dos Campos, with five AgTechs; and Piracicaba with 38 AgTechs.

The information researched on the websites was branch of activity, business partnerships in projects and connections, connections with associations, accelerators, universities, and 
incubators. An Excel spreadsheet database was created to list all AgTechs, the products and services offered, and the links with the three communities.

NetDraw software was used to map social networks, making it possible to view the network, and Ucinet, which is a Windows program designed to analyze social networks, made it possible to understand the existing relationships between São Paulo's AgTechs by using the affiliations command to build one-mode networks from two-mode networks.

\section{Findings}

Searching in the ABStartups database, it was found 350 AgTechs linked to the association were found, 90 are in the state of São Paulo, 49 in Minas Gerais, and 45 in Rio Grande do Sul, 42 in Paraná, and 124 are distributed in other 20 states.

The state of São Paulo stands out for the number of AgTechs (90), from those $26 \%$ operates in the agribusiness sector in Brazil. São Paulo's AgTechs are distributed in three communities: ZeroOnze (São Paulo capital), with the highest number of AgTechs; AgTech Valley (Piracicaba) with the second highest number; and Parahyba Valley community (São José dos Campos) with the third highest number. These communities can seek joint solutions to overcome challenges (Baggio \& Baggio, 2015). The distribution is shown in Figure 1.

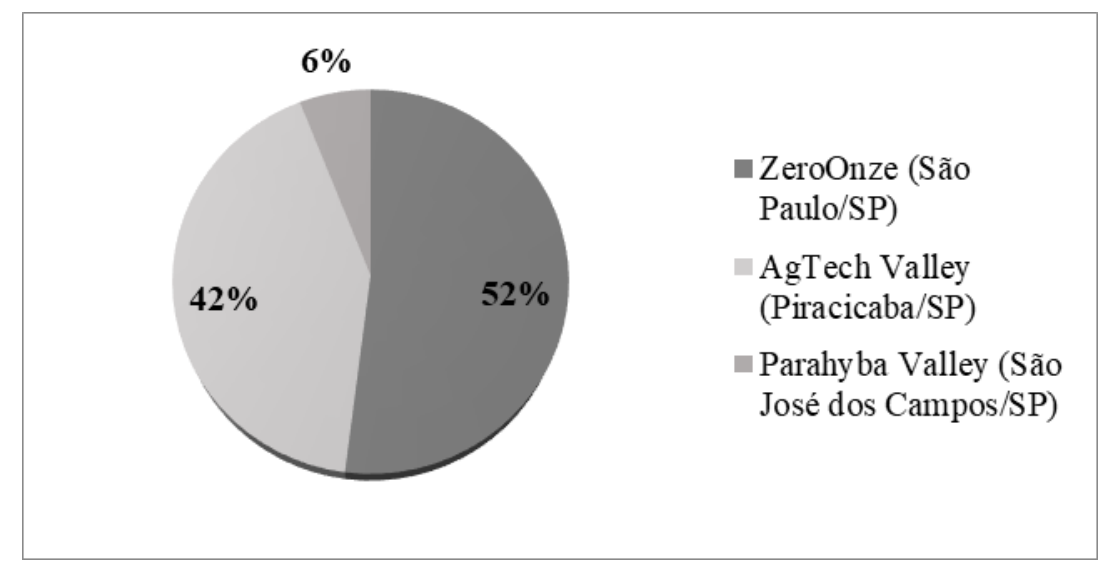

Figure 1: Distribution of AgTech communities in the state of São Paulo. Source: Authors (2020).

The investments in technological development leaded Brazilian AgTechs to prosper at a fast pace. In addition, maintaining a balance between internal and collaborative R\&D activities has a positive impact on growth, especially during the economic slowdown or crisis (Marullo et al., 2020).

According to Associação Brasileira de Startups (2019), 44\% of them create management software, drones, and sensors, another $22 \%$ invest in marketing platforms development, and $15 \%$ in data management. In other words, these are companies that invest significantly in technology and focus on technological entrepreneurship in the agribusiness sector (Global Startup Ecosystem Report, 2018).

The research was conducted in three startup communities and then to identify the amount of Agtechs in each of them. Thus, 90 firms were identified. Comprising three communities, São Paulo AgTech consists of 90 firms. Of these firms, 42 offer management platforms; 14 provide platforms for marketing products and services and bringing suppliers closer to consumers; 16 offer products and services focused on biotechnology; 8 offer different services and products; 
2 provide marketing platforms; and 8 were not identified due to lack of information on the websites consulted or because they do not have active sites (see Figure 2).

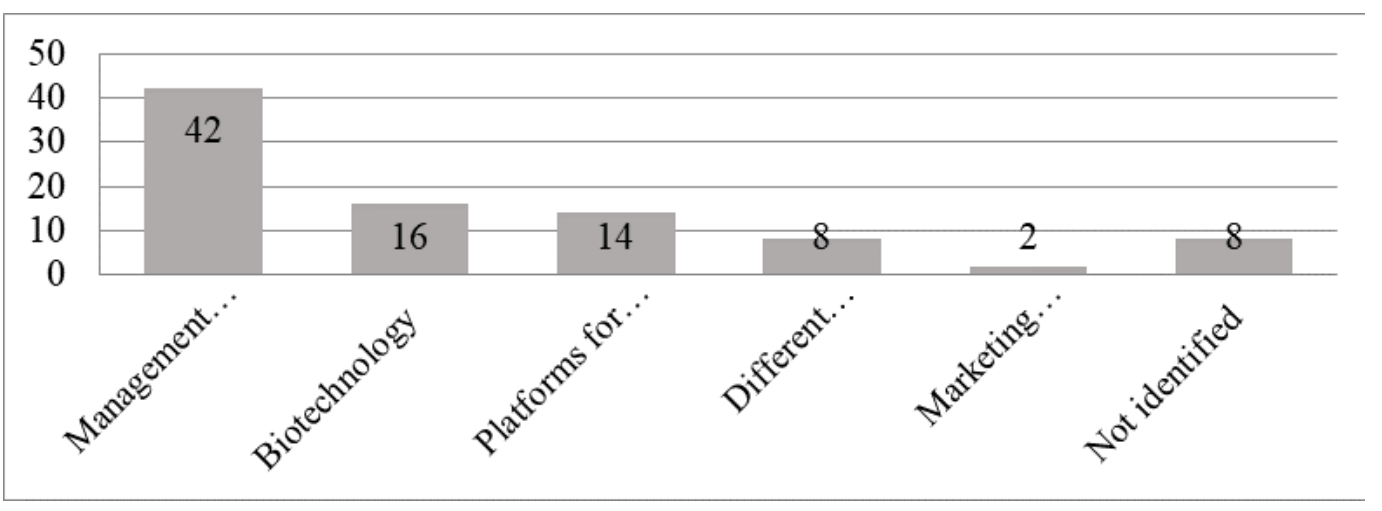

Figure 2: Products and services offered by AgTechs in the state of São Paulo.

Source: Authors (2020).

Once AgTechs were identified, the products and services offered were investigated. The division followed the specialty criteria: management platforms, which are those products and services used to manage rural properties; marketing platforms, which are products and services that bring suppliers and consumers together; biotechnology applied to inputs, such as modified seeds; automated marketing platforms focused on increasing sales; and various products and services, such as 3D printing and rain induction. It was not possible to locate the products and services offered by eight AgTechs from São Paulo due to the lack of information on the websites or to the absence of an active website.

The Table 2 presents fourteen AgTechs and describe the sectors in which startups operate and what are the products and services offered to the market, in addition to physical location. Thus, three startups were chosen from each segment, the latter of which presented only two startups. Other characteristics of those 14 startups, organized by segment of developed technologies and showing the customer segments, main partners, and location are presented.

The products and services offered by the AgTechs aim to reduce costs, increase profits, optimize the application of inputs, decrease environmental pollution, and reduce waste, and they align with Shiratsuchi (2012) study on precision agriculture. The use of new information technologies transforms the work in the field, increases productivity, and enables a better knowledge of production, thereby facilitating the decision-making of rural entrepreneurs (Tschiedel \& Ferreira, 2002). On the other hand, the multiplicity of activities products and services developed in the Ecosystem reinforces the diversity of specializations required to meet the demands (Marjotta-Maistro et al., 2019).

Moreover, this diversity has been observed in the most debated cases of innovative entrepreneurship ecosystem formation what indicates the advantages that diversity brings to the generation of disruptive innovations as pointed out in Silicon Valley (2019), which include artificial intelligence, cloud computing, and technology applied to agribusiness. Thus, the development of technologies that allow greater control of agricultural and livestock production, as well as the creation of marketing platforms, are a promising market for AgTechs (Brasil, 2019). 


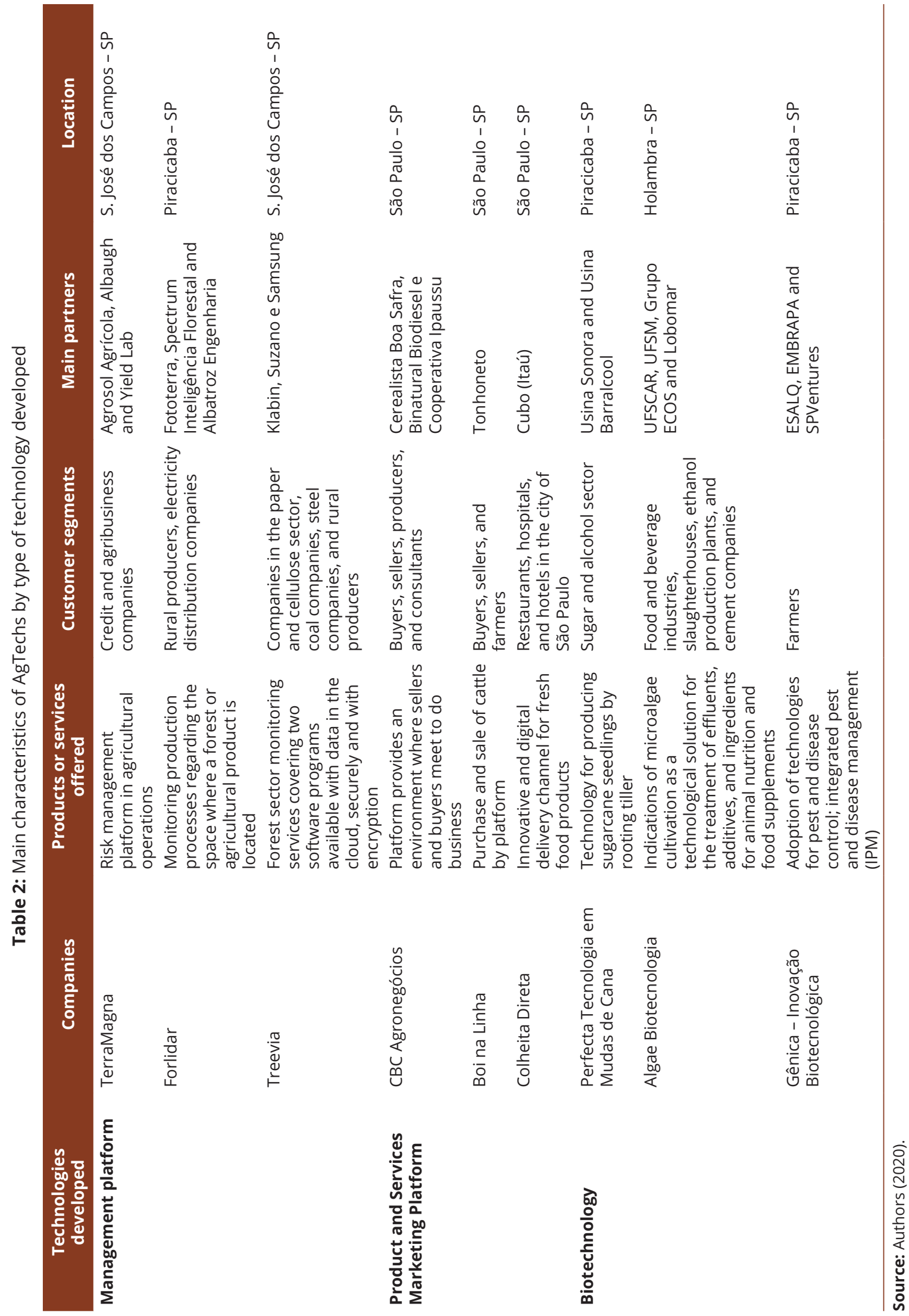




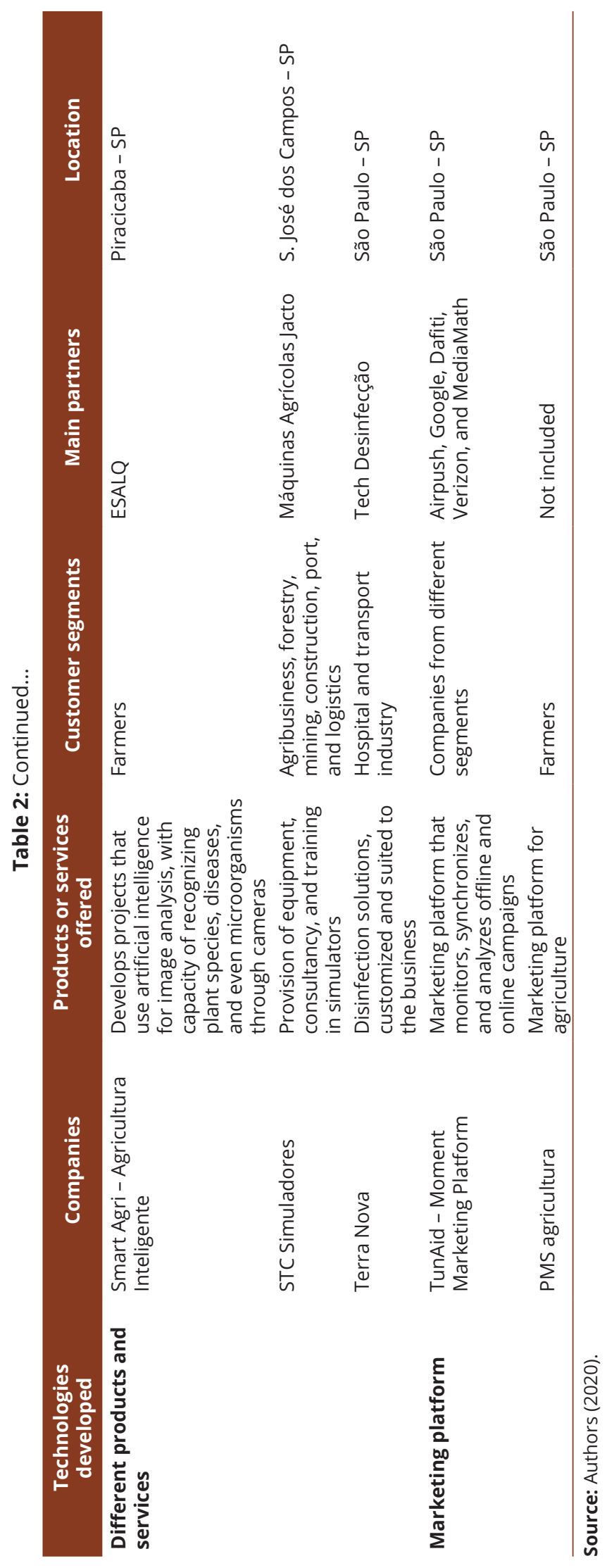


The ZeroOnze community is in São Paulo and consists of about 2,500 startups from different sectors. Among them, 47 startups are AgTechs (ZeroOnze, 2019), offering products and services such as waste management, marketing, management and marketing platforms, aerial images, weather forecasting, probiotics production, rain induction, and drone mapping. This community has its own website, promotes meetings called "company parties" to exchange experiences and share knowledge, and provides chat rooms called "Slacks" for specific subjects to promote interaction between members. The community reinforces the importance of exchanging information and knowledge in the search for technological solutions (Feld, 2012), interpersonal relationships, and participation in industry events to exchange experiences among members of a network of companies (Toigo, 2018).

The Parahyba Valley community, located in São José dos Campos, one of the largest Brazilian technology hubs, comprises 52 startups, five of which are AgTechs whose products and services offered are risk management, forest management, simulators, forest monitoring and, analysis platforms for agricultural areas. The community is linked to the São José dos Campos Technological Park and has more than 300 companies and startups, innovation hubs, incubators, technology parks, and accelerators. The interactions with external agents to promote innovation are guided by trust, partnership, and learning that facilitate the development of new technological products and services (Silva et al., 2016). There are mentoring programs and leading universities such as ETEP, Fatec, ITA, Unesp Guaratinguetá, and USP Lorena (Associação Brasileira de Startups, 2019). The startup Agronow offers a digital platform for the analysis of agricultural areas. As an indication of the attractiveness of AgTechs in new markets and the exponential boost to growth, in 2018 the community sold a minority stake to the financial institution BTG Pactual, which provides agricultural insurance (Mendes, 2019). EMBRAPA and the São José dos Campos Technological Park (PQTEC) signed an agreement in the second half of 2018 to promote technological development in the field, in partnership with rural producers, attracting companies from the agribusiness sector and those that develop technological solutions (Parque Tecnológico São José dos Campos, 2019). In this community, members participate in sector fairs with collective stands, increasing the visibility of their products and services with a lower cost of exposure (Parque Tecnológico São José dos Campos, 2019). Thus, the formation of relationship networks between companies is important for increasing the competitiveness and efficiency of the network's members (Nagano et al., 2010).

The AgTech Valley community is in Piracicaba city in the state of São Paulo, a region whose history is linked to agribusiness. The community aims to promote the development of companies and educational institutions, attract new members, and strengthen the culture of innovative collaboration. The community of startups includes 86 organizations, from those, 38 are AgTechs, 5 are innovation hubs, 1 is a technological incubator, 1 coworking center, 6 university's labs, 11 are research centers, 1 is a one cooperative of sugar cane producers, and six are firms related to the tourist sites management (AgTech Valley, 2019).

The various products and services offered include aviary management systems, crop monitoring, consulting, forest monitoring, biotechnology, drone production, biotechnology, agricultural monitoring, and management and marketing platforms that enable social interactions, through the formation of networks, to impact on organizational and marketing innovations (Hoffmann et al., 2016). The innovation ecosystem is formed through the interaction between different actors whose objective is to offer innovative products and services to the market (Santos et al., 2020).

AgTechs are connected to the external agents, such as funding agencies, universities, and research centers, and these relationships are important for the promotion of innovation 
and the exchange of knowledge (Silva et al., 2016). The formation of effective ties among the members of the communities is in line with the study of Audretsch et al. (2019), who consider such ties as amounting to an ecosystem. Likewise, the role of accelerators is important in the growth and strengthening of startups, because accelerators connect the startups with large companies, generate opportunities, and increase the network of contacts.

The mapping of AgTechs and their communities through SNA aims to understand the existing relationships and the general structure of a network, as explained by Leonardo et al. (2019). It is important to highlight that the formation of the network is considered a strategic tool that generates value and provides benefits from social capital (Farina et al., 2013). In the case of AgTechs in the state of São Paulo, the network consists of communities of startups, as shown in the graph in Figure 3, which uses NetDraw 2.166 and Ucinet version 6 software to depict the communities and their members.

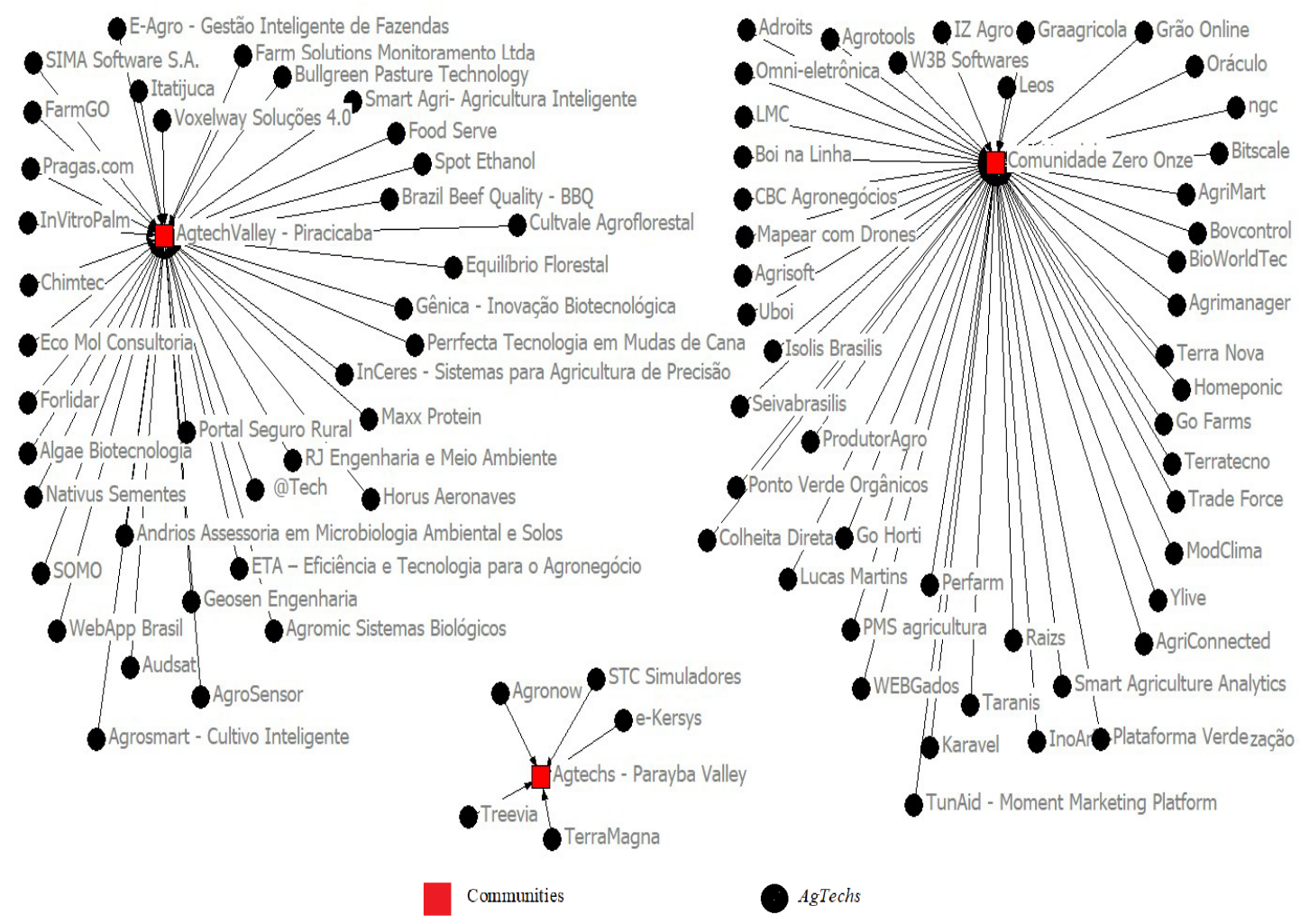

Figure 3: São Paulo AgTech network.

Source: Authors (2020).

In the network structure represented by the graph, the measure of degree centrality (degree) identifies the nodes, which are the communities linked (as shown by the lines) to the AgTechs in São Paulo. The bonds or relationships established by the network's members are important components for the analysis of social networks (Borgatti et al., 2002; Fialho, 2014; Freitas, 2010).

The mapping of the AgTech network in the state of São Paulo, using data collected on the websites of ABStartups, the three communities, and the AgTechs, made it possible to create a graph that shows the relationships and interactions between the members, using NetDraw 2.166 and Ucinet version 6, as shown in Figure 4. 


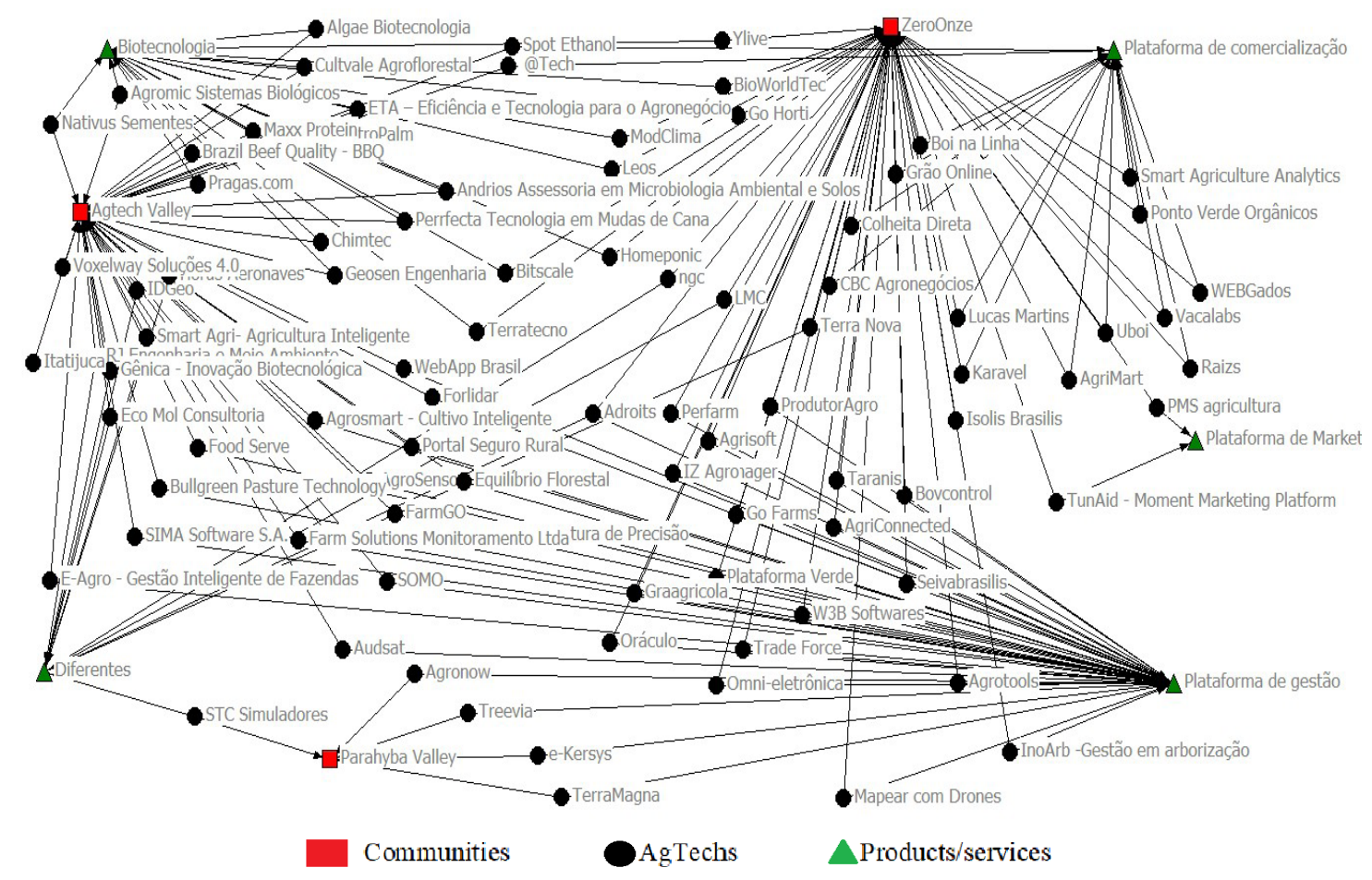

Figure 4: São Paulo AgTech network: Products and services.

Source: Authors (2020).

Figure 4 shows the network obtained from AgTechs and communities linked by the products and services offered (two-mode network analysis). The network presents the set of products and services in biotechnology; these products and services are offered by several startups from the ZeroOnze and AgTech Valley communities apart from the Parahyba Valley AgTechs. Marketing platforms are services offered only by AgTechs from the ZeroOnze community. Commercialization platforms are offered by members of the AgTech Valley and ZeroOnze communities, while management platforms are offered by startups from the AgTech Valley and Parahyba Valley communities.

The products and services offered by AgTechs are of a relevant technological nature, such as software, mapping by satellites and drones, and use of the latest technology to solve problems, reduce costs, and increase productivity. They represent a technological evolution that aims to meet food demand and to guarantee global food security (Molin, 2003). Thus, the convergence of information and communication technology with other resources has contributed to the improvement of the management and monitoring processes of agricultural production (Molin, 2003). In this sense, Lima (2019) described the main technologies used in the agricultural sector and contributing to the sustainable management of natural resources and to an increase in the productivity and income of rural producers.

Technological developments in the agribusiness sector are being monitored in real time by CBinsights (2019), an American research company that has developed a digital platform with information on growth, technology, and business and investment opportunities.

With the increasing use of information technology and the internet, satellites, and artificial intelligence, entrepreneurs can realize the interaction between innovation, knowledge, and entrepreneurship, and, consequently, boost the main drivers of economic, social, cultural, and economic development (Malerba \& McKelvey, 2019). Thus, the emergence of startups focused 
on the agribusiness sector is a wave within a technological revolution that has altered the sector and attracted the attention of large investors, a development confirmed by the increasing number of AgTechs both in Brazil and globally.

Considering Brazil's position among the largest food producers in the world, and since agribusiness was responsible for at least $26,6 \%$ of the Goss Domestic Product, in 2020 (Confederação da Agricultura e Pecuária do Brasil, 2021), it is understood that the improvement of innovation and entrepreneurship ecosystems in agribusiness, with the introduction and development of digital technologies, can, in fact, contributes to the achievement of the second sustainable development objective (United Nations, 2015) which deals with increasing agricultural productivity and the development of technologies in the agricultural sector. However, it was not the object of this study to advance on the measurable results of this action. Thus, this gap is recorded as an opportunity for future studies.

\section{Conclusions}

The objective of the research was to map the communities of startups located in São Paulo in the agricultural sector and the respective products and services they offer. In the state of São Paulo, three communities were mapped: ZeroOnze, AgTech Valley, and Parahyba Valley.

The ZeroOnze community, located in the capital, has the largest amount of AgTechs, and the products and services offered are diverse, including digital management and commercialization platforms, biotechnology, waste management, aerial images, sensors, forest monitoring, and induction of rain. ZeroOnze promotes frequent meetings between members, creating digital platforms for conversations on specific topics.

The second largest community is the AgTech Valley, located in Piracicaba Valley, with 38 AgTechs, which are interconnected with other public and private institutions. This is the only network dedicated exclusively to the agribusiness sector. It comprises companies, a cooperative of rural producers, non-governmental organizations, and research institutions.

Parahyba Valley has the lowest number of AgTechs with five in total, but all of them offer products and services of relevant technological value. Agronow, one of the AgTechs, following the acquisition of a minority stake in the company by BTG Pactual, even moved into the financial sector in 2019 by offering agricultural insurance. This indicates not only those new possibilities for operating in the financial market are emerging, but also that AgTechs are attracting the interest of large companies, including the banking sector.

In summary, agricultural production and services in Brazil, which account for $21.4 \%$ of total GDP (2019) and 19.67\% of jobs (2019), reinforce the importance of studies of this sector, especially regarding the technological evolution that has changed paradigms and led to precision agriculture. By relying on a solid information technology infrastructure, AgTechs have the potential to generate disruptive innovations that progressively transform the economy and the agribusiness sector. They propose technological solutions that involve planning the rational use of natural resources, reducing the number of fertilizers used in crops, and adopting new varieties of more productive seedlings. The sector attracts highly qualified human resources and accelerates the development of new products and services.

The rapid growth of startups, including AgTechs, reflects an evolution in the commercial relationship among agricultural producers and solution providers, since they are oriented to identify answers targeted at specific needs of producers. The AgTechs are aligned with the UN Agenda 2030 and the EMBRAPA program, because they adopt a technological response to the challenge of increasing agricultural productivity, improving soil conservation, and reducing 
costs. They contribute by enhancing rural producers' capacity to meet the global demand for food and nutritional security. In addition, the solutions generated by AgTechs can create new job opportunities, increase income, and reduce the external dependence on technology goods.

The network analysis of products and services in the areas of biotechnology, business management, marketing, and commercialization offered by the AgTechs suggests promising directions for future studies on the nature of the relationships and exchanges among members of the AgTech communities and on the cocreation process of technological solutions between AgTechs and their communities. In addition, future research can use SNA to map AgTechs in other states, other Brazilian startup communities, and entrepreneurial ecosystems related to the agribusiness sector. Studies can contact experts, members of those communities, and AgTechs owners aiming to expand knowledge about the topic considered in this paper.

\section{References}

AgTech Garage. (2019). Retrieved in 2019, March 19, from https://www.AgTechgarage.com/censo/ AgTech Valley. (2019). Retrieved in 2019, March 19, from https://www.esalq.usp.br/valedopiracicaba

Almeida, L. C. F. D. (2007). Avaliação energética econômica da cultura do milho em assentamento rural, (Doctoral dissertation). UNESP, Iperó. Retrieved in 2019, March 25, from https:// repositorio.unesp.br/handle/11449/137353

Associação Brasileira de Startups - ABStartups. (2019). Banco de dados StartupBase. Retrieved in 2019, March 25, from: https://startupbase.com.br/.

Audretsch, D. B., Cunningham, J. A., Kuratko, D. F., Lehmann, E. E., \& Menter, M. (2019). Entrepreneurial ecosystems: economic, technological, and societal impacts. The Journal of Technology Transfer, 44(2), 313-325. http://dx.doi.org/10.1007/s10961-018-9690-4

Baggio, A. F., \& Baggio, D. K. (2015). Empreendedorismo: conceitos e definições. Revista de empreendedorismo, inovação e tecnologia, 1(1), 25-38. https://doi.org/10.18256/23593539/reit-imed.v1n1p25-38.

Balestrin, A., \& Verschoore, J. R. (2007). Relações interorganizacionais e complementaridade de conhecimentos: proposição de um esquema conceitual. Revista de Administração Mackenzie, 8(4), 153-177. Retrieved in 2019, March 25, from https://www.redalyc.org/ articulo.oa?id=1954/195415184008

Bernardi, A. D. C., Naime, J. D. M., Resende, A. D., Inamasu, R. Y., \& Bassoi, L. (2014). Agricultura de precisão: resultados de um novo olhar. Retrieved in 2019, March 25, from http://www. infoteca.cnptia.embrapa.br/infoteca/handle/doc/1002959

Borgatti, S. P., Everett, M. G., \& Freeman, L. C. (2002). Ucinet for Windows: software for social network analysis (Vol. 6). Harvard, MA: Analytic technologies.

Brasil. Ministério da Agricultura, Pecuária e Abastecimento - MAPA. (2018). Projeções do agronegócio. Retrieved in 2019, March 25, from https://www.gov.br/agricultura/pt-br/ assuntos/politica-agricola/todas-publicacoes-de-politica-agricola/projecoes-do-agronegocio/ banner_site-03-03-1.png/view

Brasil. Ministério da Economia - ME. (2019). Retrieved in 2019, March 25, from http://www. economia.gov.br/

CBinsights. (2019). AgTech and the Connected Farm. Retrieved in 2019, March 25, from https:// www.cbinsights.com/research/briefing/ag-tech-trends-connected-farming/ 
Centro de Estudos Avançados em Economia Aplicada - CEPEA. (2019). Boletim CEPEA Mercado de trabalho do agronegócio brasileiro. Retrieved in 2019, March 25, from https://www. cepea.esalq.usp.br/br/mercado-de-trabalho-do-agronegocio.aspx

Centro de Estudos Avançados em Economia Aplicada - CEPEA. (2020). BR Agribusiness GDP from 1996 to 2019 (Monthly Growth Rate, Values of Brazilian Agribusiness GDP, segments, and its share in the Brazilian Total GDP - 1995 to 2018). Retrieved in 2019, March 25, from https://www.cepea.esalq.usp.br/en/brazilian-agribusiness-gdp.aspx

Christensen, C. M. (2013). The innovator's dilemma: when new technologies cause great firms to fail. Boston: Harvard Business Review Press.

Conceição, L. A., \& Braga, R. (2015). Montagem e calibração de um sistema de monitorização de colheita numa ceifeira debulhadora. Retrieved in 2019, March 25, from https://www. researchgate.net/publication/280001253_Montagem_e_Calibracao_de_um_Sistema_de_ Monitorizacao_numa_Ceifeira_Debulhadora

Confederação da Agricultura e Pecuária do Brasil - CNA. Centro de Estudos Avançados em Economia Aplicada - CEPEA. (2021). Agribusiness GDP reaches $26.6 \%$ share in Brazilian GDP in 2020. Retrieved in 2019, March 25, from https://www.cnabrasil.org.br/boletins/ pib-do-agronegocio-alcanca-participacao-de-26-6-no-pib-brasileiro-em-2020

Cunha, F. J. K., Mendes, L. M. A. G., \& Zambonini, J. G. A. (2019). O uso da tecnologia como aporte ao agronegócio. Revista Científica Multidisciplinar Núcleo do Conhecimento, 5, 22-35 Retrieved in 2019, March 25, from https://www.nucleodoconhecimento.com.br/tecnologia/ aporte-ao-agronegocio

Davis, C., \& Tomoda, Y. (2018). Competing incremental and breakthrough innovation in a model of product evolution. Journal of Economics, 123(3), 225-247. http://dx.doi.org/10.1007/ s00712-017-0568-y

Empresa Brasileira de Pesquisa Agropecuária - EMBRAPA. (2018). Visão 2030: o futuro da agricultura brasileira. Retrieved in 2019, March 25, from https://www.embrapa.br/en/ busca-de-publicacoes/-/publicacao/1090820/visao-2030-o-futuro-da-agricultura-brasileira

Farina, M. C., Silva, R. S., Silva Filho, J. R. T., Silveira, M. A. P., Ozaki, M. T., \& Benevides, G. (2013). Uma investigação da centralidade e da densidade de uma rede de empresas que atuam na realização de festas e de casamentos. Revista Alcance, 20(2), 170-185. http://dx.doi. org/10.14210/alcance.v20n2.p170-185

Feld, B. (2012). Startup communities: building an entrepreneurial ecosystem in your city. New York: John Wiley \& Sons.

Fialho, J. (2014). Análise de redes sociais: princípios, linguagem e estratégias de ação na gestão do conhecimento. Perspectivas em Gestão \& Conhecimento, 4, 9-26.

Fiuza-Moura, F. K., Nakatani-Macedo, C. D., Câmara, M. R. G., \& Sesso Filho, U. A. (2017). Criação e destruição de empregos no setor primário no Brasil entre 2000 e 2009. Revista de Economia e Sociologia Rural, 55(01), 137-156. Retrieved in 2019, March 25, from https:// www.revistasober.org/article/10.1590/1234-56781806-94790550108/pdf/resr-55-1-137.pdf

Freeman, C., \& Perez, C. (1988). Structural crises of adjustment, business cycles and investment behaviour. New York: Routledge.

Freeman, C., \& Soete, L. (1997). The economics of industrial innovation (Psychology Press). New York: Routledge. 
Freitas, L. Q. (2010). Medidas de centralidade em grafos (Doctoral dissertation), Universidade Federal do Rio de Janeiro. Retrieved in 2019, March 25, from http://objdig.ufrj.br/60/teses/ coppe_m/LeandroQuintanilhaDeFreitas.pdf

Gil, A. C. (2019). Métodos e técnicas de pesquisa social (7. ed.). São Paulo: Editora Atlas SA.

Global Entrepreneurship Monitor - GEM. (2017). Relatório Executivo 2017: empreendedorismo no Brasil. Retrieved in 2019, March 25, from https://m.sebrae.com.br/Sebrae/Portal\%20 Sebrae/Anexos/Relat\%C3\%B3rio\%20Executivo\%20BRASIL_web.pdf

Global Startup Ecosystem Report. (2018). Succeeding in the new era of technology. Retrieved in 2019, March 25, from https://startupgenome.com/reports/global-startup-ecosystemreport-gser-2018

Global Startup Ecosystem Report. (2020). The new normal for the global startup economy and the impact of COVID-19. Retrieved in 2019, March 25, from https://startupgenome.com/ report/gser2020

Hanneman, R. A., \& Riddle, M. (2005). Introduction to social network methods. Riverside: University of California.

Hoffmann, V. E., Junior, E. R., Danda, G. N., \& Veloso, Y. S. (2016). A influência da estrutura sociorrelacional do empreendedor na capacidade inovativa de empresas incubadas de base tecnológica. Redes: Revista hispana para el análisis de redes sociales, 27(1), 113-128.

Instituto Brasileiro de Geografia e Estatistica - IBGE. (2019). Panorama do Brasil. Retrieved in 2019, March 25, from https://cidades.ibge.gov.br/brasil/panorama

Isenberg, D. (2011, May 25). Introducing the entrepreneurship ecosystem: four defining characteristics. Forbes. Retrieved in 2019, March 25, from https://www.forbes.com/sites/ danisenberg/2011/05/25/introducing-the-entrepreneurship-ecosystem-four-definingcharacteristics/\#621f9a5b5fe8

Kondratieff, N. D. (1935). The long waves in economic life. The Review of Economics and Statistics, 17(6), 105-115.

Leonardo, S. B., Farina, M. C., Andreoli, T. P., \& Lima, A. P. M. B. D. (2019). Relacionamentos interpessoais formal e informal: interação das redes no ambiente acadêmico. Revista de Administração Contemporânea, 23(3), 395-415. http://dx.doi.org/10.1590/19827849rac2019180045

Liga Insigths AgTech. (2019). Retrieved in 2019, March 25, from https://insights.liga.ventures/.

Lima, V. A. (2019). Atividades de inovação na agricultura de precisão do Brasil: uma análise na perspectiva dos sistemas de inovação tecnológica (Doctoral dissertation). Universidade Municipal de São Caetano do Sul, São Caetano do Sul.

Magalhães, R., \& Vendramini, A. (2018). Os impactos da quarta revolução industrial. GV Executivo, $17(1), 40-43$.

Malerba, F., \& McKelvey, M. (2019). Knowledge-intensive innovative entrepreneurship. Foundations and Trends in Entrepreneurship, 14(6), 555-681. http://dx.doi.org/10.1561/0300000075.

Marjotta-Maistro, M. C., Montebello, A. E. S., \& Santos, J. A. (2019). Desafios do agro empreendedorismo: as startups do campo. Brazilian Journal of Development, 5(9), 1494914964. http://dx.doi.org/10.34117/bjdv5n9-092

Marullo, C., Piccaluga, A., Cesaroni, F. (2020). How to invest in R\&D during downturns? Exploring the differences between fast-growing and slow-growing high-technology SMEs. Rivista Piccola Impresa/ Small Business, (1), 143-160. http://dx.doi.org/10.14596/pisb.330 
Mauri, G. D. N., Lima, J. G., Chévez Pozo, O. V., \& Freitas, R. R. (2017). Startups no agronegócio brasileiro: uma revisão sobre as potencialidades do setor. Brazilian Journal of Production Engineering, 3(1), 107-121. Retrieved in 2019, March 25, from https://periodicos.ufes.br/ bjpe/article/view/v3n1_10

Mendes, L. H. (2019, January 17). BTG compra fatia de startup agrícola que passou por sua aceleradora. Jornal Valor Econômico. Retrieved in 2019, March 25, from https://www.valor. com.br/agro/6069305/btg-compra-fatia-de-startup-agricola-que-passou-por-sua-aceleradora

Miranda, A. C. C., Veríssimo, A. M., \& Ceolin, A. C. (2017). Agricultura de precisão: um mapeamento da base da Scielo. Gestão.Org: Revista Eletrônica de Gestão Organizacional, 15, 129-137. http://dx.doi.org/10.21714/1679-18272017v15Ed.p129-137

Molin, J. P. (2003). Agricultura de precisão: situação atual e perspectivas. Milho: Estratégias de Manejo para Alta Produtividade, 1, 89-98.

Moori, R., Shibao, F. Y., \& Santos, M. R. (2018). Role of technology in the environmental performance of the Brazilian chemical industry. Revista de Administração Mackenzie, 19(1), http://dx.doi.org/10.1590/1678-6971/eRAMR180094

Nagano, M. S., lacono, A., \& Escrivão Filho, E. (2010). Cooperação, interação e aprendizado em sistemas locais de produção: evidências em empresas brasileiras. Revista Africana de Gestão de Negócios, 4(12), 2459.

Nelson, R., \& Winter, S. G. (1982). Uma teoria evolutiva da mudança econômica (pp. 929-964). Campinas: Editora Unicamp.

Noce, M. (2017). Análise do processo de transferência de tecnologia no sistema de integração lavoura-pecuária-floresta, para agricultores familiares na região central de Minas Gerais (Doctoral dissertation). Universidade Federal de Viçosa, Viçosa. Retrieved in 2019, March 25, from https://www.locus.ufv.br/handle/123456789/12365

Padrão, L. C., \& Andreassi, T. (2013). O desempenho de Startups de base tecnológica: um estudo comparativo em regiões geográficas brasileiras. Revista da Micro e Pequena Empresa, $7(2), 66-79$.

Parque Tecnológico São José dos Campos - PqTec. (2019). Retrieved in 2019, March 25, from http://www.pqtec.org.br/en-us/

Perez, C. (2010). Technological revolutions and techno-economic paradigms. Cambridge Journal of Economics, 34(1), 185-202.

Santos, I. C., Freire, J. R. S., \& Lima, V. A. (2020). The brazilian scientific agricultural research ecosystem: an evolutionary trajectory in ST\&I. Revista Brasileira de Gestao e Desenvo/vimento Regional, 16(2), 79-88

Schumpeter, J. A. (1935). The analysis of economic change. The Review of Economics and Statistics, 17(4), 2-10. http://dx.doi.org/10.2307/1927845

Sesso Filho, U. A., Borges, L. T., Sesso, P. P., Brene, P. R. A., \& Esteves, E. G. Z. (2022). Mensuração do complexo agroindustrial no mundo: comparativo entre países. Revista de Economia e Sociologia Rural, 60(1), e235345. http://dx.doi.org/10.1590/1806-9479.2021.235345

Shiratsuchi, L. S. (2012). Agricultura de precisão: nova filosofia de trabalho na agricultura. Retrieved in 2019, March 25, from https://www.embrapa.br/documents/1354377/1743392/LucianoShozo-Agricultura-de-Precisao.pdf/a3fbe0c1-6821-4c25-8116-860a04ead104?version=1.0

Silicon Valley (2019). Retrieved in 2019, March 25, from https://www.siliconvalley.com/tag/ startups/ 
Silva, G., Dacorso, A. L. R., Costa, V. B., \& Di Serio, L. C. (2016). Relationships and partnerships in small companies: strengthening the business through external agents. BAR - Brazilian Administration Review, 13(1), 1-18. http://dx.doi.org/10.1590/1807-7692barnaahead0116

Startse. (2019). Retrieved in 2019, March 25, from www.starse.com

Toigo, T. (2018). Aprendizado de rede no contexto de intercooperação e fusão de redes: a opção de não-fusão. Revista Ibero-Americana de Estratégia, 17(4), 111-124. http://dx.doi. org/10.5585/ ijsm.v17i4.266

Tschiedel, M., \& Ferreira, M. F. (2002). Introdução à agricultura de precisão: conceitos e vantagens. Ciência Rural, 32(1), 159-163.

United Nations - US. (2015). Transforming our world: the 2030 agenda for sustainable development. Resolution adopted by the General Assembly. Retrieved in 2019, March 25, from https://sdgs.un.org/2030agenda/.

ZeroOnze. (2019). Retrieved in 2019, March 25, from http://zeroonzestartups.com.br/ 